\title{
Polityka dla miast, miasta dla polityki. O możliwości (i konieczności) radykalnej polityki miejskiej
}

\author{
„Jeśli miasto jest światem stworzonym przez człowieka, jest też światem w którym \\ odtąd przychodzi mu żyć. Przez to, pośrednio, i bez jasnej świadomości natury tego zadania, \\ tworząc miasto człowiek przekształcił sam siebie."
}

Ogólny lewicowy projekt nowego porządku światowego, mimo pokryzysowego przyśpieszenia i „wyjścia z szafy”, pozostaje raczej zbiorem postulatów niż realną wizją polityczną gotową do instytucjonalnego zaistnienia. Kolejne próby przywrócenia dziewiętnastowiecznej werwy radykalnej teorii społecznej palą na razie na panewce. Sytuacja może wprawdzie uchodzić za niosącą rewolucyjno-emancypacyjny potencjał. Jednak wszelkie próby powtórzenia marksowskiego ruchu w nowych warunkach (vide spółka Michael Hardt i Antonio Negri ${ }^{2}$ ), mimo całej finezyjnej aparatury teoretyzującej elastyczny menadżersko-spekulacyjny kapitalizm informacyjny, pozostaja cały czas raczej w oczekiwaniu na aktualizację swojej performatywnej mocy, przyczajone w oczekiwaniu na nowy proletariat, który wcieli je w czyn. Państwo narodowe jawi się jako skamieniały relikt niemogący dłużej stawiać czoła wyzwaniom współczesności ${ }^{3}$ i jak na razie nie wyłoniła się żadna nowa struktura polityczna mogąca stanąć na wysokości zadania. Lewicy zamkniętej w starej formie pozostaje tylko „reakcyjny konserwatyzm” w postaci obrony resztek państwa opiekuńczego. W obliczu niemożliwości zaprowadzenia „socjalizmu w jedynym kraju”, współcześnie określanej jako ,globalizacyjny wyścig do dna”, nie ma już miejsca na postępową wizję. Śmiałość utopii jest, zgodnie z intuicjami Karla Mannheima, dostępna tylko

\footnotetext{
${ }^{1}$ R. Park, On Social Control and Collective Behavior, Chicago 1967, s. 3.

${ }^{2}$ Zob. zwłaszcza M. Hardt, A. Negri, Imperium, thum. A. Kołbaniuk, S. Ślusarski, Warszawa 2005, s. 421-426.

${ }^{3}$ Co oczywiście na swój sposób obwieściła już Róża Luksemburg. Teraz jednak kwestia zupełnej nieprzystawalności narodowych organizmów politycznych do globalnych procesów gospodarczych stała się kluczową z punktu widzenia właściwie wszystkich opcji politycznych. Z bogatej literatury na ten temat zob. choćby L. C. Thurow, Przyszłość kapitalizmu: jak dzisiejsze sity ekonomiczne ksztaltuja świat jutra, thum. L. Czyżewski, Wrocław 1999, s. 171-176; U. Beck, Wtadza i przeciwwladza w epoce globalnej: nowa ekonomia polityki światowej, tłum. J. Łoziński, Warszawa 2005, s. 23-26.
} 
www.praktykateoretyczna.pl

tradycjonalistycznej prawicy, która usiłuje wiecznie powracać do nigdy nieistniejącej organicznej wspólnoty ${ }^{4}$.

Być może w takich warunkach, gdy poziom ogólnoświatowy ogarnia co najwyżej teoria, należy poszukać oparcia w pomniejszych całościach społeczno-przestrzennych. Do tego celu miasto nadaje się nie najgorzej. Przede wszystkim, mimo uwikłania w globalne sieci i powiązania polityczno-ekonomicze, skala procesów społecznych jest tu łatwiejsza do ogarnięcia, a stopniowe korekty stanu rzeczy łatwiejsze do konceptualnego wypracowania i instytucjonalnego wdrożenia. Mimo że gęste sieci zależności oplatają dziś każdą formę kolektywnej organizacji, to procesy społeczne zachodzące w miastach w dużej części nie wydają się bezalternatywne i nawet istniejące formy władzy mogą na nie skutecznie wpływać. Miasto może stać się tedy obszarem ocalenia polityki.

\section{Miasto - byt nieagregatowy}

Miasto jako forma organizacji społecznej i przestrzennej w samej swojej istocie zawiera mglistą obietnicę socjalizmu. Wspólne zamieszkiwanie jednego terenu i zbieżne interesy (niekoniecznie takie same, ale wzajemnie się uzupełniające czy wzmacniające - po cóż inaczej mieszkać w takim skupisku?) umożliwiają, czy nawet wymuszają komunikację, współdziałanie i elementarną formę wspólnoty. Miasto, niemal niczym Hobbesowski Lewiatan, obiecuje korzyści i ochronę, zapewnia możliwość synergicznego zaspokajania różnych potrzeb mieszkańców. W zamian wymaga zrzeczenia się pewnej części indywidualnej wolności, składanej na rzecz wykraczającego poza nią dobra wspólnego. Dzieje się to jednak w sposób odmienny, niż chcieliby teoretycy oświeconego absolutyzmu. Ponad wolę jednostkową wznosi się nie transcendentny suweren, ale samorządna wspólnota polis - idealnego politycznego bytu. Miasto jest więc poniekąd prototypem wszelkich politycznych wizji zmierzających do wykroczenia poza pozostałości klasycznej teorii suwerenności ku „wielości” komunikujących się podmiotów. Niesie nadzieję na nowe urządzenie ludzkiej wspólnoty.

$\mathrm{Na}$ pierwszy rzut oka sytuacja rzeczywistych miast przeczy tego typu nadziejom. Mimo pozornie wzrastających kompetencji miejskiego samorządu (chodzi mi raczej o długie trwanie miasta jako idei - wynalazek lokalnej, pilnującej porządku władzy wykonawczej nie

\footnotetext{
${ }^{4}$ Zob. K. Mannheim, Ideologia i utopia, tłum. J. Miziński, Warszawa 2008.
} 
jest kwestią odległej przeszłości ${ }^{5}$ ), wieścimy powszechnie upadek miast jako formy organizacji ludzkiego życia. Kryzys miast, upadek miasta jako idei politycznej (ogłoszony przez Krzysztofa Nawratka ${ }^{6}$ ) nie skłania do upatrywania w nim jutrzenki społecznej zmiany. Postępują: inwestycyjny rygor, prywatyzacja i komercjalizacja miejskiej przestrzeni, atomizacja mieszkańców - zainteresowanych coraz bardziej horyzontem indywidualnego dobrobytu, dla osiągnięcia którego ci, którzy nie wsiedli w porę do kapitalistycznego tramwaju, są nieustającą przeszkodą. W przypadku wielu miast europejskich tym, co utrwala ich spoistość, są historyczne centra, naturalnie ogniskujące aktywność mieszkańców i turystów. Tam, gdzie ich brakuje, niewiele nas dzieli od zapadłych centrów miastobwarzanków. Miasto jako spójną formę organizacji społeczno-przestrzennej utrzymuje sztucznie kościec renesansowego rynku. Jego zamieszkiwanie nie wiąże się już z jakąkolwiek formą wspólnotowości, stało się subiektywną sumą podejmowanych indywidualnie czynności produkcyjno-konsumpcyjnych ${ }^{7}$. Staje się więc tworem w pełni post-politycznym, gdzie demokracja ogranicza się do zarządzania konsekwencjami globalnych imperatywów, a polityczność skarlała do neoliberalnej rządomyślności ${ }^{8}$.

\section{Miasto - rzeczywiste miejsce podmiotu polityki}

Jeśli rzeczywiście miasto jako demokratyczno-dyssensualna wspólnota polityczna należy do przeszłości, podobnie rzecz ma się z podmiotem tak pojmowanej polityki. Zamieszkiwanie w mieście, sprowadzone do poszukiwania komfortu prywatnego życia, oznacza na tym lokalnym, ale najbardziej realnym poziomie rzeczywiste wpisanie biologicznej egzystencji w porządek wspólnoty politycznej ${ }^{9}$. Nawiasem mówiąc, miasta sytych przedmieść okazują się rewersem diagnozy Giorgio Agambena - najbardziej namacalnym przykładem zagnieżdżania jakiejkolwiek polityczności w nagim życiu ${ }^{10}$. Są więc tworami na swój sposób biopolitycznymi. Inaczej jednak, niż obwieszcza Agamben, można,

\footnotetext{
5 Stosunkowo sprawne władze municypalne i narodziny miejskiej „władzy dyscyplinarnej” to doprawdy wynalazek niedawny - wystarczy przypomnieć sobie obrazy tętniącego podskórnego życia dziewiętnastowiecznych metropolii i powstające w urbanistycznym chaosie miasta przemysłowe.

${ }^{6}$ K. Nawratek, Miasto jako idea polityczna, Kraków 2008, s. 26-27.

${ }^{7}$ Tamże, s. 31-34.

${ }^{8}$ E. Swyngedouw, The Post-Political City, [w:] Urban Politics Now: Re-Imagining Democracy in the Neoliberal City, Rotterdam 2007.

9 Taka tęsknota za politycznym życiem miasta jest przesycona intelektualnym duchem Hannah Arendt. Jest on implicytnie obecny w każdym zdaniu tego tekstu. Na temat tryumfu biologicznego życia odtwarzającego same siebie zob. tejże, Kondycja ludzka, tłum. A. Łagodzka, Warszawa 2000, s. 346-351.

${ }^{10}$ Zob. G. Agamben, Homo sacer: suwerenna władza i nagie życie, tłum. M. Salwa, posł. P. Nowak, Warszawa 2008 .
} 
wychodząc ,stąd”, pomyśleć drogi przekroczenia takiej kondycji i przywrócenia znaczenia życiu społeczno-politycznemu. Jeśli biologiczne życie zostało już raz wpisane w mechanizmy władzy i stało się obiektem jej oddziaływania, to dzieje się tak właśnie w lokalnym kontekście zamieszkiwanej przestrzeni, w której owa władza się materializuje. To w mieście, a nie w państwie czy na poziomie ONZ, rozgrywa się rzeczywiste życie (tym razem bez predykatu) coraz liczniejszych jednostek ludzkich. Warunki tego życia pozostają w zwrotnym związku z polityką, w której ono partycypuje. Miasto jako miejsce narodzin polityczności, życia społecznego i publicznego, jest dalej z nimi ściśle związane. To w nim realizuje się większość tego typu aktywnego życia i można próbować, balansując na cienkiej linii uwiedzenia przez władzę, przywrócić wymiar polityczny wspólnotowemu życiu, tworząc odpowiednie ramy do jego zaistnienia ${ }^{11}$.

Miasto, jak odnotowaliśmy wyżej, immanentnie zawiera $\mathrm{w}$ sobie pierwiastek przemocy związany z wymogami wspólnotowego życia. Nawratek powiada, że owa „pusta przemoc" wyzbyta konotacji imperialnych czy mrocznego uwikłania w opresyjną plemienność, stanowi fundament miejskości. Zmuszając do interakcji i kontaktu, może dać początek odnowie miasta $\mathrm{w}$ postaci wspólnoty politycznej ${ }^{12}$. W obliczu bezwyjściowego uwikłania $\mathrm{w}$ sieci ujarzmienia ${ }^{13}$ i raczej mglistych $\mathrm{i}$ nieprzekonujących perspektyw mesjańskiego wyzwolenia $\mathrm{z}$ bycia nagim życiem ${ }^{14}$, próba przywrócenia wspólnotowopolitycznego oblicza miast, wykorzystująca ową dospołeczną przemoc, zdaje się warta podjęcia. Obarczona jest wprawdzie in nuce figurą oświeconego suwerena i perspektywą pewnej inżynierii społecznej. Jednak ten niepopularny komponent jest konieczny, by

\footnotetext{
${ }^{11}$ Wspólnota miejska to byt, który umyka łatwemu definiowaniu. To, jak ją określimy, wynika właściwie z przyjętej wizji polityczności. Może to być polityczność liberalna, oparta na racjonalnej argumentacji w sferze publicznej, wspólnota wprzódy ustanowionych wolnych podmiotów (Arendt, Jürgen Habermas, Leo Strauss) czy też dyssensualna polityczność „radykalnej demokracji” (Ernesto Laclau, Chantal Mouffe), albo ciągłego brania pod uwagę nowych podmiotowości (Jacques Rancière). Obie zresztą odwołują się do greckiego pierwowzoru polis. Nie nam tu rozstrzygać między nimi. W przypadku dzisiejszego miasta na ten moment wystarczy przyjąć propozycję Nawratka: polis to ,wspólnota zamieszkująca określone terytorium, która jest na tyle samoświadoma, że sama potrafi sobą zarządzać" (Miasto jako idea..., s. 195). Niezależnie od tego, jak sfera polityczna będzie określona, $\mathrm{z}$ pewnością $\mathrm{w}$ dzisiejszych miastach praktycznie zanikła, a przedpolityczne warunki jej odbudowy są tematem naszych rozważań.

${ }^{12}$ K. Nawratek, Miasto jako idea..., s. 188-193.

${ }^{13}$ Nawiązuję tu oczywiście do teorii władzy dyscyplinarnej i procesów upodmiotowienia opracowanych przez Focaulta, zob. zwłaszcza tegoż, Nadzorować i karać: narodziny więzienia, tłum. T. Komendant, wyd. 2, Warszawa 1998

${ }^{14} \mathrm{Na}$ temat możliwości przekroczenia kondycji homo sacer, mesjańskiego wyzwolenia i raczej antypolitycznego oblicza przyszłej wspólnoty proponowanej przez Agambena zob. zwłaszcza teksty E. Laclau, Nagie życie czy spoleczne niewiadomo co?, tłum. K. Szadkowski czy A. Bielik-Robson, Rozbita konstelacja: teologia Agambena między tragediq a mesjanizmem, [w:] Agamben: Przewodnik „Krytyki Politycznej”, oprac. zbiorowe, wstęp M. Ratajczak, K. Szadkowski, Warszawa 2010, s. 35-54 oraz 141-196.
} 
pomyśleć przestrzenny i temporalny początek zmiany, której miejscem jest miasto, a czasem dzisiaj.

\section{Zmaterializowane wartości}

Kształt rzeczywistości społecznej jest wypadkową wielu czynników: oprócz procesów makrostrukturalnych jest to też suma codziennych indywidualnych decyzji. Tak, jak decyzje konsumenckie kształtują światowe rynki, tak najdrobniejsze wybory użytkowników miejskiej przestrzeni odmieniają jej oblicze. Czym pojadę dziś do pracy? Gdzie spędzę wieczór? W jakiej okolicy zamieszkam? Czy będzie to osiedle strzeżone? Gdzie uczyć się będą dzieci? Kwestie te nie są z góry rozstrzygnięte mocą jakichś globalnych kosmologii, ale są za każdym razem skrupulatnie rozważane przez indywidualny ludzki podmiot. Tak oto wizja jednostki racjonalnie kalkulującej każdą decyzję rodem z neoklasycznej ekonomii czy teorii gier, może być zaprzęgnięta w służbę słusznej sprawie. Jasne jest, że decyzje te mogą być podejmowane wbrew „obiektywnym” czynnikom - mocą etycznej czy społecznej świadomości lub pragnienia realizacji jakichś wyższych celów. Jednak, w zdecydowanej większości przypadków będą wypadkową kalkulacji kosztów i tego, do jakich wyborów zachęcają nas okoliczności.

Bruno Latour, w czasach gdy był bardziej filozofem nauki niż polityki, trafnie opisał sposoby, w jakie ludzie współpracują z przedmiotami, i jak określa to ich postępowanie. Klasyczne teorie socjologiczne zapoznawały ten wymiar ludzkiego zachowania, opisując tylko interakcję symboliczną między ludźmi. Tymczasem Latour pokazał, jak nieoczywiste są nasze pozornie mechaniczne albo przeciwnie - przypisywane autonomicznej woli, decyzje i działania. Przedmioty codziennego użytku czy infrastruktura różnego rodzaju, mogą być naszych działań partnerem, Latour powiada ,aktantem”, który na równi z nami, świadomymi podmiotami, wpływa na podejmowane przez nas kroki. „Materialność i socjalność współtworzą się albo są po prostu dwoma stronami tych samych procesów."15 Owe artefakty zaś często nie są przypadkowe, a zupełnie intencjonalnie przez kogoś wcześniej kształtowane (projektantów, prawodawców, wykonawców). W tej oto materialności zaklęte są pewne informacje, prawo, wartości, które aktualizują się w interakcji z człowiekiem poprzez jego działanie. Owe normy delegowane na rzeczy powodują, że z dużym prawdopodobieństwem

\footnotetext{
${ }^{15}$ K. Abriszewski, Poznanie, zbiorowość, polityka: analiza teorii aktora-sieci Bruno Latoura, Kraków 2008, s. 213.
} 
www.praktykateoretyczna.pl

użytkownik zrealizuje właśnie ten program, który jest mu przeznaczony. Samochód z brzęczykiem sygnalizującym niezapięte pasy, aktywnie działa na użytkownika i odwodzi go od realizacji antyprogramu - niezapięcia pasów. Nie musi on już charakteryzować się wysoką świadomością etyczną, mieć zinternalizowanych norm poruszania się po drogach, nie musi nawet obawiać się mandatu, ani w ogóle zastanawiać się, dlaczego pasy warto zapiąć. Po prostu dla świętego spokoju to zrobi.

Gdzież znajduje się moralność? We mnie, kierowcy - człowieku zdominowanym przez bezmyślną siłę artefaktu? Czy też w artefakcie zmuszającym mnie, bezmyślnego człowieka do przestrzegania prawa, które dobrowolnie zaakceptowałem odbierając swoje prawo jazdy ${ }^{16}$ ?

W podobny sposób zachodzą również bardziej skomplikowane relacje z materialną rzeczywistością - jeśli brelok będzie za ciężki, oddam klucz hotelowy do recepcji. Jeśli parking będzie płatny i spodziewać się będę surowej kary za parkowanie na trawniku, a alternatywą będzie szybki i bezpieczny przejazd rowerem lub autobusem, być może zostawię samochód w domu, albo wcale go nie kupię.

Jest to zmyślna translacja możliwego programu opierającego się na moralności na program opierający się na twardej konieczności [...]. Odległość między moralnością a siłą nie jest tak szeroka, jak oczekują etycy, a dokładniej rzecz biorąc, zmyślni inżynierzy uczynili ją mniejszą ${ }^{17}$.

Jak widać znaczenie ,regulacyjnej” urbanistyki okazuje się nadzwyczaj ważkie dla samej konstytucji podmiotów miejskiego życia. Robert Moses zaprojektował nowojorskie mosty w sposób uniemożliwiający poruszanie się autobusom, z których korzystała czarnoskóra ludność (by odciąć ją od miejskich parków) ${ }^{18}$. Tak jak zabieg ten delegował segregację rasową na infrastrukturę drogową (a przy okazji wymusił korzystanie z samochodu na każdym, kto tylko miał taką możliwość), tak też osiągalna jest odwrotna - „wkluczająca” polityka miejska, realizująca w materialności lewicowe wartości.

\footnotetext{
${ }^{16}$ B. Latour, Where Are the Missing Masses?: Sociology of a Few Mundane Artefacts, [w:] Shaping Technology, Building Society: Studies in Sociotechnical Change, red. W. Bijaker, J. Law, Cambridge 1992, s. 255, cyt. za K. Abriszewski, Poznanie..., s. 217.

${ }^{17}$ B. Latour, Where Are the Missing Masses.., cyt. za K. Abriszewski, Poznanie.., s. 220.

${ }^{18}$ Zob. R. Sennett, Ciało i kamień: czlowiek $i$ miasto w cywilizacji zachodu, thum. M. Konikowska, Gdańsk 1996, s. 285.
} 
Owe transportowe ilustracje są tylko przykładem (choć obejmującym zadziwiająco dużo powiązanych procesów kształtujących współczesne miasta) tego, jak rożne instrumenty dostępne od ręki w miejskiej polityce (a nawet w postpolitycznym, komunalnym zarządzaniu) mogą wpływać na kształt rzeczywistości społecznej. Regulacje prawne, fiskalne, czynszowe, polityka transportowa, mieszkaniowa, zagospodarowanie przestrzenne, plany miejscowe, czy inwestycje komunalne dają niezwykle szerokie pole do politycznej decyzji i starań o przywrócenia miastu dospołecznego oblicza. Dodatkowo, wcale nie muszą być one wynikiem proklamowania jakiejś ogólnej bitwy o miejską hegemonię, wystarczy, że aktualizują się w pojedynczych regulacjach dotyczących najdrobniejszych spraw miejskiej wspólnoty. Doskonale pojęli tę prawdę wszelcy aktywiści i ruchy miejskiego protestu, ogniskując swe działania na bardzo konkretnych, niekiedy błahych kwestiach, które jednak składają się na całokształt społecznego życia. Komitet blokowy stawiający słupki osłaniające trawnik jest w walce o miasto potężnym sojusznikiem.

\section{Ale ja nie chcę! Tym gorzej dla Ciebie.}

Podstawowa aporia, którą należy rozwikłać, to rzekoma sprzeczność takich działań z indywidualną wolą mieszkańców, którzy przecież chcą używać codziennie swojego SUV-a, zamieszkiwać strzeżone domki na przedmieściach i zamienić parki na parkingi. Gdyby było inaczej, to po pierwsze, mogliby wyzwolić się $z$ tej opresji i dać wyraz swojemu niezadowoleniu poprzez głosy w wyborach samorządowych, po drugie zaś, mogliby po prostu postępować inaczej, jeździć rowerem i mieszkać w komunalnej kamienicy w centrum. Ich wybór, święte prawo. Celowo do odparcia takiego argumentu przeciw postępowej polityce miejskiej nie chcę używać metateoretycznych ekwilibrystyk współczesnej myśli radykalnej. Miejska biedota, chyba trafnie określana jako „uniwersalna część bez przydziału”, która może wznieść się ponad partykularne interesy jednostek i grup społecznych, którym zapewnia reprezentację model liberalny. Argumentacja taka jest jednak znakomicie nieprzydatna w realnej walce o kształt miasta - na poziomie sąsiedzkich sporów, kampanii organizacji pozarządowych czy pracy samorządu.

Imperialistyczne państwo narodowe końca XIX wieku „obiektywnie” sprzyjało interesom kapitału, choć często występowało przeciw poszczególnym kapitalistom. Umożliwiało poskromienie indywidualnych działań, które $\mathrm{w}$ dłuższej perspektywie prowadziłyby do nadwyrężenia całego systemu relacji społeczno-ekonomicznych. Było gwarantem interesu ponadjednostkowego (choć oczywiście owo „dobro wspólne” było 
www.praktykateoretyczna.pl

dalekie od czegokolwiek, co moglibyśmy uznać za uniwersalne). W podobny sposób immanentna miastu przemoc realizuje ponadjednostkowy sens wspólnoty. Nie chodzi już jednak o interes (dziś wędrownego) kapitału, jak w powyższym przykładzie - choć oczywiście tak działa to $\mathrm{w}$ wielu dzisiejszych ośrodkach miejskich. Tym razem musimy aktem etycznej decyzji opowiedzieć się za wartościami, które chcemy realizować. Jest to akt wiary nie mający metafizycznego umocowania (chyba, że akurat mamy takie pod ręką - w religii, uniwersalnych wartościach, telosie dziejów, rewolucyjnym zbawieniu - co kto woli). Owa proklamowana miejska wspólnota może być i pustym znaczącym, gdzie każdy z nas włoży bliskie sobie treści. Może być jedyną szansą uniknięcia narastających społecznych napięć, drogą zapewnienia społecznej spójności i solidarności, unikiem przed krwawą kulminacją (co może też trącić cynicznym reformizmem - jeśli jednak by tak było, pozostaje nam logika „im gorzej, tym lepiej”, właściwa pierwszym rosyjskim marksistom, sprzyjającym wyzyskowi jako akuszerowi rewolucji). W każdym zaś razie, dospołeczna przemoc daleka jest od totalitarnych tęsknot za idealnym miastem, właściwie jest już i tak uprzednio obecna w jakiejkolwiek formie współżycia. Część z niej jest niezbędną przemocą kolektywu, ale reszta jest owym nadmiarem, który decyduje o kształcie rzeczywistości. Skala ograniczenia wolności, jakiej poddane są jednostki, nie zmienia się. Otoczenia miasta kapitalistycznego preferuje, a nawet wymusza, bardzo konkretne zachowania, które takoż można zmienić. Mocą opowiedzenia się po jednej (lewej) stronie, musimy zwiększyć wymogi stawiane wspólnocie by pozwolić jej na rozwój. Nie w imię jakiejś abstrakcyjnej wiecznie niezrealizowanej filozoficznej antropologii czy śnionej przez pokolenia marksistów dezalienacji ale dla owej mocy jakiegokolwiek społecznego współistnienia trzeba podjaćc ów jeszcze jeden wysiłek. W kapilarnych końcówkach, gdzie materializuje się dyscyplinarna władza i wymuszane programy naszych działań, kryje się również potłuczony okruch władzy kolektywu, prowadzący do bycia razem, do ,zaczepienia ludzi swoimi brakami” ${ }^{19}$. Rezygnacja z tego wymiaru oznacza ostateczne zapadnięcie się jednostek w sferze prywatnej konsumpcji, zatracenie horyzontu czegoś, co decydowało o wyswobodzeniu się z okowów biologiczności, finalną rezygnację $\mathrm{z}$ wykraczania poza rządzoną imperatywem komfortu ,zasadę

\footnotetext{
${ }^{19}$ K. Nawratek, Miasto jako idea..., s. 140 i n.
} 
przyjemności” ${ }^{20}$. Upadłe miasto jako suma konsumentów to ponowny tryumf ,idiotyzmu życia wiejskiego"21, z którego miejska forma życia tak skutecznie niegdyś wyrywała.

\section{W obronie czlowieczeństwa?}

Richard Sennett, przyglądając się w foucaultowskim duchu ${ }^{22}$ miejskim ciałom, określa całą historię miast jako batalię o oblicze ciała-podmiotu miejskiego życia ${ }^{23}$. Materialna przestrzeń miasta to ciagły bój między pragnieniem odseparowania, braku kontaktu, biologicznego „solipsyzmu”, a wszczepianiem świadomości własnej niekompletności, wymuszaniem kontaktu, komunikacji i otwarcia na innego. Miasto nie tylko stoi u źródeł polityki i stanowi jej najgłębszą zasadę, realizuje też fundamentalny ruch cywilizacji jako takiej.

Oto jak działa cywilizacja: stawia nas słabych i kruchych w obliczu sprzecznych doznań, których nie da się odepchnać, z których winy czujemy się niepełni. Lecz właśnie w takim stanie „dysonansu poznawczego" człowiek skupia uwagę na innych obszarach, zaczyna je badać, zaczyna się po nich poruszać: to obszary, gdzie niemożliwa jest przyjemność wynikająca z pełnej harmonii ${ }^{24}$.

Miasto gaszące komfortem świadomość podmiotowej niekompletności jest miastem zamknięcia na innego. Po ucieczce w indywidualną wolność rynku umiera polityka, znika, tym razem miejski, rynek i zredukowany zostaje społeczny aspekt człowieka, który stanowił co najmniej od Arystotelesa o jego człowieczeństwie. Jak widać, podmiot, również polityczny, nie jest czymś ahistorycznym i źródłowym. Być może, gdy już raz rozpoznaliśmy jego przygodność, tym bardziej możemy czuć się zobligowani do obrony takiego jego kształtu, jaki wytworzył samą tę świadomość. Inaczej, ostatecznie ześlizgniemy się ku rezygnacji z pozabiologicznego wymiaru człowieczeństwa.

\footnotetext{
${ }^{20}$ Wątek Freudowski pojawia się tu nie tylko jako inspiracja do gry słów - powrót do „prenatalnego” stanu bez bodźców wywołujących napięcia, czyli właśnie w pełni zrealizowana libidalna ekonomia poddana zasadzie przyjemności, to odwieczne pragnienie człowieka, które nigdy nie może być zrealizowane. Zob. Z. Freud, Poza zasada przyjemności, tłum. J. Prokopiuk, Warszawa 1994; R. Sennett, Ciało i kamień ..., s. 293.

${ }^{21}$ Zob. K. Marks, F. Engels, Manifest Partii Komunistycznej, [w:] Dzieła wybrane, t. 1, Warszawa 1981, s. 374.

${ }^{22}$ Sennett współpracował zresztą z Foucaultem pod koniec jego życia. Napisali też razem jeden artykuł: Sexuality and Solitude, "Humanities in Review" 1982, No. 1, s. 3-21.

${ }^{23}$ R. Sennett, Ciało i kamień ..., s. 298.

${ }^{24}$ Tamże, s. 293-294.
} 
Nie bez powodu Hippodamos, bodaj pierwszy urbanista („,wynalazł sztukę planowania miast”), został przez Arystotelesa zaliczony w poczet „filozofów” politycznych. Przestrzeń uprawiania polityki jest ustalana wcześniej przez ustrój - takoż prawny, jak i przestrzenny. By wspólnota polityczna mogła funkcjonować, musi mieć do tego odpowiednie ramy ${ }^{25}$. Procesy społeczne dzisiejszych miast są z pewnością bardziej złożone, jednak do zaistnienia życia politycznego niezbędne są nadal, po części przedpolityczne, warunki możliwości, pośród których jest też struktura przestrzenna. Nawratek trafnie określa problem, ale być może zbyt łatwo pozbywa się choćby tymczasowych i inicjujących środków niosących jego przezwyciężenie.

\begin{abstract}
Miasta subiektywne to problem przede wszystkim polityczny i społeczny, a dopiero w następnej kolejności przestrzenny. Reintegracja przestrzeni miejskiej nie da się więc przeprowadzić narzędziami urbanistycznymi. Urbanistyka jako taka czy planowanie przestrzenne mają coraz mniejsze znaczenie właśnie dlatego, że ich rola stała się czysto regulacyjna, instrumentalna i ekspercka ${ }^{26}$.
\end{abstract}

Nawet jeśli tak rzeczywiście jest, to gdzie miałaby się zacząć owa odnowa polityki? Jeśli kryzys miasta przyniosły przemiany przestrzenne i transportowe ${ }^{27}$, to być może należy założyć, że od nich, jako kształtujących podmioty polityki, należy zaczać przywracanie wymiaru politycznego. Oznaczałoby to, że urbanistyka, właśnie jako ,regulacyjna i instrumentalna", może być wykorzystana do modelowania przyszłego życia politycznego. Jeśli rozpoznaliśmy dokładnie mechanizmy działania dyscyplinarnej władzy, która wymusza określoną produkcję podmiotów miejskiego życia, dlaczego „tymczasowo” jej nie wykorzystać, by zatrzymać niekorzystny kierunek zmian i przywrócić szanse na zaistnienie realnej, politycznej współegzystencji miejskich obywateli? Dopiero równolegle z taką przestrzenną ,akupunkturą"28 podatnych politycznych ciał można by tworzyć realne mechanizmy uczestnictwa w miejskiej wspólnocie. Dlatego nie można pochopnie rezygnować

\footnotetext{
${ }^{25}$ Dlatego Hippodamos mógł stanowić ustrój państwowy, ale nie musiał być mężem stanu. „[B]ył pierwszym, który nie będąc czynnym mężem stanu, pokusił się by coś powiedzieć o najlepszym ustroju" (Arystoteles, Polityka, 1267 B, thum. i komentarze L. Piotrowicz, wstęp M. Szymański, Warszawa 2004, s. 60). Po części prawodawca, po części rzemieślnik, wytwórczo, przedpolitycznie, wytwarza dopiero warunki możliwości agory wolnych obywateli. Zob. też P. Nowak, Wolność albo życie, [w:] H. Arendt, Kondycja ludzka, s. 359.

${ }^{26}$ K. Nawratek, Miasto jako idea..., s. 34.

${ }^{27}$ Co zresztą stwierdza sam Nawratek: tamże, s. 28.

${ }^{28}$ Takie określenie $\mathrm{w}$ odniesieniu do praktyk produkcji podmiotowości indywidualnych i instytucjonalnych, zaproponowała w rozmowach prywatnych Agata Zysiak. Jest ono o tyle trafne, że pozwala uwypuklić niejednoznaczny zwrot aksjologiczny tych praktyk, opartych na władzy, ale mogących mieć „lecznicze” działanie.
} 
z prostych, i być może przez to pozornie nieskutecznych, narzędzi. Nawratek ma wprawdzie rację powiadając, iż „tym, co wydaje się jedynym skutecznym remedium, byłoby odzyskanie Miasta jako idei politycznej, jako samozarządzającego sobą organizmu”29. Wbrew Nawratkowi jednak wypada przyznać, że urbanistyka, programy społeczne i wreszcie poszczególne miejskie walki, nawet jeśli nie są uniwersalną receptą na renesans polityki, to stanowią jego początkowy warunek.

Lokalne wykorzystanie oddziaływania miejskiej władzy jako środka realizującego zmiany transmitowane $\mathrm{w}$ kierunku top-bottom w dłuższej perspektywie może dać szansę wytworzenia potencjału politycznego obywatelstwa odgrywającego rolę również na ogólniejszym poziomie ${ }^{30}$. Tym razem byłaby to zmiana bottom-top, a taki scenariusz umożliwia pomyślenie przeciwstawienia się pozornie bezalternatywnym zmianom globalnym. Jeśli to tu, na jednostce, w jej namacalnym życiu i codziennych sprawach, kończy się łańcuch oddziaływań władzy, to dlaczego nie uczynić tego punktu locus zmiany tejże władzy. Tym samym w pełni wykorzystać intuicję Foucaulta, że ,jednostka jest efektem władzy, a jednocześnie, w takiej mierze, w jakiej jest jej efektem, jest jednocześnie jej trybem, przez który władza przechodzi”,31, a zatem, dopowiemy, może być też przezeń zmodyfikowana ${ }^{32}$.

Polityka jest ratunkiem dla miast, ale i miasta są ratunkiem dla polityki. Chodzi jednak nie o abstrakcyjne działanie polityczne, la politique pour la politique, ale najdrobniejsze miejskie walki i, przede wszystkim, przywrócenie miastu oblicza zmuszającego do spotkania. Powinniśmy z pełną świadomością konsekwencji ponownie określić prospołeczność miast jako podstawowy ich fundament, ale i kluczowy warunek jakiekolwiek wspólnego życia. Wpisać go niejako w każdy dostępny element rzeczywistości, lokalne prawodawstwo,

\footnotetext{
${ }^{29}$ K. Nawratek, Miasto jako idea..., s. 34.

30 Jest też oczywiście możliwa analiza praktyk życia miejskiego niejako od drugiej strony, w duchu „wynajdywania codzienności” zaproponowanym przez Michela de Certeau. Mieszkańcy dokonują swoistej korupcji odgórnej „strategii” władzy (administracji, kapitału etc.) poprzez nieuprawnione użycia, kłusownictwo rozbijające funkcjonalny imperatyw technik systemowych, podstępy wymierzone $\mathrm{w}$ scentralizowana architektonikę władzy właścicielskiej (tegoż, Wynaleźć codzienność: sztuki działania, tłum. K. Thiel-Jańczuk, Kraków 2008, s. 35-37). Pomijam tu ten aspekt (choć jest on istotny dla powodzenia każdego przedsięwzięcia miejskiego), by uwypuklić sprawczą rolę owej „strategicznej” władzy w kształtowaniu podmiotów politycznych. Jest to zamierzenie skażone ciagłą, niemal dialektyczną oscylacją między poziomami - władza świadomie rozpościerana nad jednostką krzyżuje się w polach sił z jej sprzeciwem, jednocześnie lokując ją jako podmiot - i tworząc przedpolityczne warunki zaistnienia polityki, w najbardziej pierwotnym sensie.

${ }_{31}$ M. Foucault, Trzeba bronić społeczeństwa: wyklady w College de France 1976, thum. M. Kowalska, Warszawa 1998, s. 39.

${ }^{32} \mathrm{Nie}$ chodzi mi tu o modyfikację $\mathrm{w}$ rodzaju kłusownictwa, ale ciagłe zwrotne naddeterminowanie obu poziomów. De Certeau zresztą w swojej krytyce „wczesnego" Foucaulta nie uwzględnia późniejszych rekonfiguracji ujęcia władzy, w których jednostkowe taktyki oporu zostały w zasadzie „wciągnięte” w obręb oddziałującego dyspozytywu (M. Foucault, Wola wiedzy, tłum. B. Banasiak, K. Matuszewski, [w:] tegoż, Historia seksualności, wstęp T. Komendant, Warszawa 1995, s. 82-92; tegoż, Power/Knowledge: Selected Interviews and Other Writings 1972-1977, red. C. Gordon, New York 1980, s. 194-198.
} 
www.praktykateoretyczna.pl

najdrobniejsze przepisy, kapilarne końcówki miejskiej władzy i otaczającą nas materialność, na którą mamy jakikolwiek wpływ. Takie obiektywizowanie norm, wartości, pewnego imperatywu etycznego $\mathrm{w}$ otaczającej nas przestrzeni materialnej i symbolicznej jest jak najbardziej możliwe i osiaggalne z poziomu władzy lokalnej, organizacji pozarządowych, obywatelskich grup nacisku, a nawet komitetu blokowego. To właśnie może stanowić ożywczy napęd dla wszystkich tego typu działań. Opatrzenie walki o słupki przed blokiem sztandarem walki o zachowanie cywilizacji może się wydawać nazbyt górnolotne. Bez wątpienia, takie właśnie jest. Ale to właśnie pojęcie tej sytuacji zmusza nas do politycznego działania.

Wiktor Marzec, Politics for cities, cities for the political. About possibility (and necessity) of radical urban politics

Summary: Essay faces the problem of determinacy of global capitalism processes for the reality of urban political life. The city is naturally communitarian form of human life and seems to be the place where radical pro-community politics could be undertaken. Already existing and operating forms of power could fruitfully influence the city social relations. Values and norms of conduct are broadly delegated on the urban space and materiality, thus conscious shaping of city space has severe consequences for community life. If a crisis of the political partly has its roots in metamorphoses of the cities, then also remedies, rising from the urban materiality and reestablishing political subjects, could be thought. City, as most real place of political life could be either reduced to the aggregate of consumers or reestablished as a political community. Due to this is the place where undesired course of action could be stopped, hence precisely here the radical democratic politics can emerge.

Key Words: city, urban policy, politics, the political, political community, town planning, power, city space. 